\title{
Public Health Technology Assessment: niet horen, niet zien en zwijgen!
}

Citation for published version (APA):

Evers, S. M. A. A. (2013). Public Health Technology Assessment: niet horen, niet zien en zwijgen! Maastricht University. https://doi.org/10.26481/spe.20130201se

Document status and date:

Published: 01/02/2013

DOI:

10.26481/spe.20130201se

Document Version:

Publisher's PDF, also known as Version of record

\section{Please check the document version of this publication:}

- A submitted manuscript is the version of the article upon submission and before peer-review. There can be important differences between the submitted version and the official published version of record. People interested in the research are advised to contact the author for the final version of the publication, or visit the DOI to the publisher's website.

- The final author version and the galley proof are versions of the publication after peer review.

- The final published version features the final layout of the paper including the volume, issue and page numbers.

Link to publication

\footnotetext{
General rights rights.

- You may freely distribute the URL identifying the publication in the public portal. please follow below link for the End User Agreement:

www.umlib.nl/taverne-license

Take down policy

If you believe that this document breaches copyright please contact us at:

repository@maastrichtuniversity.nl

providing details and we will investigate your claim.
}

Copyright and moral rights for the publications made accessible in the public portal are retained by the authors and/or other copyright owners and it is a condition of accessing publications that users recognise and abide by the legal requirements associated with these

- Users may download and print one copy of any publication from the public portal for the purpose of private study or research.

- You may not further distribute the material or use it for any profit-making activity or commercial gain

If the publication is distributed under the terms of Article $25 \mathrm{fa}$ of the Dutch Copyright Act, indicated by the "Taverne" license above, 

"Public Health Technology Assessment: niet horen, niet zien en zwijgen!" 
Maastricht University

Faculty of Health, Medicine and Life Sciences

CAPHRI, School for Public Health and Primary Care

Department of Health Services Research

Focusing on Chronic Care and Ageing

Postbus 616, 6200 MD Maastricht

T: 043-3881570

www.maastrichtuniversity.nl/hsr

\section{Contact}

Prof. dr. mr. S.M.A.A. Evers

s.evers@maastrichtuniversity.nl

www.caphri.nl/silviaevers

\footnotetext{
Cover: $\quad$ Datawyse / Universitaire Pers Maastricht

Afbeeldingen: Voorkant “Mama's werk", Lara Muijrers, Achterkant "De wereld", Vera Muijrers Lay-out \& Printing: Datawyse / Universitaire Pers Maastricht

(C) Copyright Maastricht University, Faculty of Health, Medicine and Life Sciences CAPHRI, School for Public Health and Primary Care, Department of Health Services Research, 2013.

Niets uit deze uitgave mag gekopieerd of overgenomen worden zonder uitdrukkelijke toestemming van de auteurs.
} 


\section{"Public Health Technology Assessment: niet horen, niet zien en zwijgen!"}

Oratie uitgesproken op 1 februari 2013

door Prof.dr.mr. Silvia MAA Evers, Maastricht University, Faculty of Health, Medicine and Life Sciences, Maastricht ter aanvaarding van haar bijzonder hoogleraarschap met als titel "Public Health Technology Assessment: niet horen, niet zien en zwijgen!"

\section{Augustus 2014}

Prof. dr. mr. Silvia M.A.A. Evers

Maastricht University

Faculty of Health, Medicine and Life Sciences

CAPHRI, School for Public Health and Primary Care

Department of Health Services Research

Focusing on Chronic Care and Ageing 


\section{Inhoudsopgave}

$\begin{array}{lll}\text { 1. Inleiding } & 6\end{array}$

2. Publieke gezondheid en integrale zorg 7

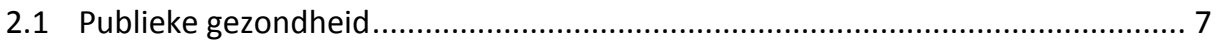

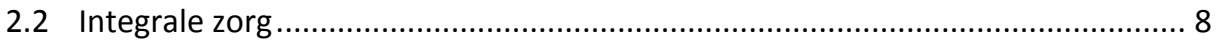

3. Health Technology Assessment en economische evaluatiestudies 10

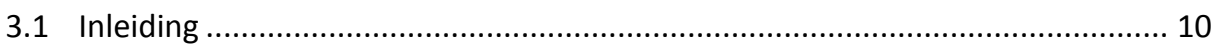

4. Drie Mythes over (Public) Health Technology Assessment 14

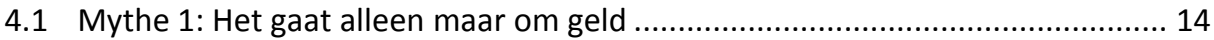

4.2 Mythe 2: Mijn behandeling is goedkoper dus het is zeker kosteneffectief........ 15

4.3 Mythe 3: Prioriteiten stellen, eerst effectonderzoek, dan economische

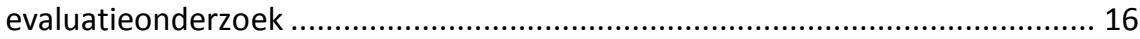

5. Public Health Technology Assessment: niet horen, niet zien en zwijgen! 20

6. Methodologische uitdagingen voor Public Health Technology Assessment: horen, zien en niet zwijgen!

6.1 Kosten en opbrengsten buiten de gezondheidszorg

6.2 Bredere uitkomstmaten; proces uitkomsten en uitkomsten naast gezondheid 23

6.3 Kwaliteit van leven voor specifieke doelgroepen ............................................ 24

6.4 Public Health Technology Assessment: te weinig data beschikbaar ................. 25

7. Horen, zien en niet meer zwijgen: voor onderwijs en management 27

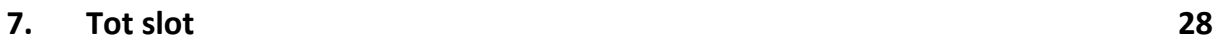

8. Dankwoord 31

$\begin{array}{ll}\text { Referenties } & 34\end{array}$ 
ORATIE PROF. DR. MR. S.M.A.A. EVERS 


\section{Inleiding}

Geacht College van Bestuur, decaan Faculty of Health Medicine and Life Sciences, College van Toezicht, zeer gewaardeerde collega's, beste familie, vrienden en overige toehoorders, ... Velen van jullie vinden het spannend en ik ook... Lieve Lara, lieve Vera, dit is het onderdeel waar jullie het minst naar uit hebben gezien; het komende dikke half uur gaat mama weer raar praten, daarna barst het feest los.

De afgelopen maanden sinds mijn benoeming als hoogleraar per 1 maart 2012, hebben vele mensen mij gevraagd "Wat ga je nu doen?" De vraag "Wat ga je nu doen?" kan ik op twee manieren beantwoorden, een makkelijke manier en een complete manier. De meesten van jullie heb ik de afgelopen maanden afgescheept met het gemakkelijke antwoord "Ik blijf hetzelfde doen als ik altijd al deed". In mijn functie verandert niets, alleen de titel, ik blijf onderzoek en onderwijs geven op het gebied van gezondheidseconomie, meer specifiek blijf ik kijken naar de kosten en opbrengsten van behandelingen in de zorg. Ook de inhoud van mijn functie blijft hetzelfde, ik blijf programmaleider van de groep die zich binnen Maastricht inzet voor onderzoek op het gebied van de gezondheidseconomie en "Health Technology Assessment" en ik blijf onderwijs coördineren op dit gebied. Aan jullie wazige blikken was vaak te zien, dat jullie dit antwoord maar niets vonden en vinden; daarom voor jullie in deze inaugurele rede of oratie het meer complete antwoord op jullie vraag. Om jullie meer inzicht te geven in mijn dagelijkse doen en laten ga ik jullie vertellen over mijn specifieke vakgebied dat we "Public Health Technology Assessment" noemen. "Public Health Technology Assessment" bestaat uit twee onderdelen "Public Health" en "Health Technology Assessment (HTA)".

Ik ga jullie iets vertellen over "Public Health" en over "Health Technology Assessment". Ik ga vervolgens in op de uitdagingen die onderzoekers in ons vakgebied staan te wachten als ze "Health Technology Assessment" toepassen in de "Public Health". Daarbij zal ik meer specifiek ingaan op de onderzoeksagenda die wij in Maastricht hebben als het gaat om "Public Health Technology Assessment". Ten slotte, is onderzoek maar één van de vele facetten die belangrijk is binnen de universiteit. Onder mijn motto "horen, zien en niet zwijgen!" wil ik graag aan het einde van de lezing aandacht besteden aan de aspecten onderwijs en management van een universiteit. 


\section{Publieke gezondheid en integrale zorg}

Hoewel in mijn structuurrapport en plan van aanpak zijn vermeld dat ik het "Health Technology Assessment" onderzoek breed, dus kijkend naar alle behandelingen in de zorg, zal ondersteunen, is mijn leerstoel in het bijzonder ingesteld om onderzoek binnen het gebied "Public Health" en "Integrated Care" vorm te geven. Anders gezegd gaat het dus om het doen van "mijn soort" onderzoek, "Health Technology Assessment", op het gebied van publieke gezondheidszorg en integrale zorg. Een definitie van beide begrippen is, zeker in het Nederlands, niet gemakkelijk te geven.

\subsection{Publieke gezondheid}

"Public Health" is een breed begrip en veel definities zijn onvolledig of te uitgebreid. Om publieke gezondheid te typeren gebruik ik de bekende oude definitie van Winslow uit 1920, te weten "Public Health" is: "the science and art of preventing disease, prolonging life and promoting health through the organized efforts and informed choices of society, organizations, public and private, communities and individuals". In enigszins goed Nederlands is publieke gezondheid de wetenschap en de kunst om ziektes te voorkomen, levens te verlengen en gezondheid te bevorderen door georganiseerde inspanningen en geïnformeerde keuzes van samenlevingen, organisaties (publiek en privaat) van de gemeenschap en van de individuele burgers. Preventie en gezondheidsbevordering zijn belangrijke aspecten van publieke gezondheid. Het gaat hierbij vaak om onderwerpen zoals stoppen met roken, matig alcohol gebruik, gezond eten, en omgaan met psychische problemen.

Binnen de publieke gezondheid zijn recent een aantal ontwikkelingen gaande die leiden tot een andere kijk op dit vakgebied. Als eerste worden behandeling en interventies steeds meer afgestemd op de individuele patiënt door gebruik te maken van allerlei informatie over de betreffende patiënten, oftewel "personalised health care". Daarnaast is in Nederland in toenemende mate aandacht voor een positieve benadering van gezondheid, dit wordt ook wel de salutogene benadering genoemd. Een voorbeeld hiervan is het thema van het Nederlands Congres Volksgezondheid 2013, passie voor volksgezondheid. In navolging van Antonovsky staat in deze benadering, het vermogen van mensen om ondanks stressvolle gebeurtenissen, gezondheid, kwaliteit van leven en welzijn te behouden centraal. 
Het gaat hierbij om thema's als gezond ouder worden, gezonde voeding, maar ook om mentale veerkracht en zelfredzaamheid.

Kenmerkend voor publieke gezondheidzorg is, dat het zich richt op zaken waar burgers niet snel om zullen vragen, maar die wel nodig zijn voor een gezonde samenleving, in het bijzonder voor risicogroepen. Bij risicogroepen gaat het om kwetsbare groepen, zoals mensen met een lager inkomen, jongeren, ouderen en mensen met psychische problemen of een verslaving.

Publieke gezondheidzorg vult daarmee de reguliere, individugerichte zorg aan, die vooral gericht is op de medisch curatieve zorg van patiënten op het moment, dat hun gezondheid geschaad is. Publieke gezondheid omvat dus het stimuleren van gedrag om gezond te leven of om behandelingen te optimaliseren. Dit soort hulp is in toenemende mate belangrijk, omdat de grenzen van de medische zorg langzamerhand worden bereikt. Daarbij is de achterliggende gedachte dat klachten moeten worden voorkomen, dat vroegtijdig moet worden ingegrepen als mensen klachten ontwikkelen en dat de gevolgen van ziektes beperkt moeten worden. Oftewel, voorkomen is beter dan genezen. Onderzoek heeft uitgewezen dat eerder ingrijpen vaak ook kosteneffectief is. Echter in tijden van bezuinigingen zijn uitgaven voor de publieke gezondheid en preventie een continue punt van discussie. Een voorbeeld hiervan is het recente advies van het College voor Zorgverzekeringen aan de minister om geïndiceerde preventie van depressie, te zien als hulp bij klachten, en deze niet te vergoeden. Dit advies past wellicht in de idee van de zorgverzekeringswet, maar staat haaks op het gedachtengoed van voorkomen is beter dan genezen.

\subsection{Integrale zorg}

Ongezond gedrag, gezondheidsachterstand en ziekte zijn niet alleen kenmerken van individuen, maar worden ook sterk bepaald door de sociale en fysieke omgeving waarin mensen geboren worden, opgroeien en leven. Zorg in het algemeen en publieke gezondheid in het bijzonder vergt daarom een intensieve en integrale aanpak oftewel "integrated care". "Integrated care" of integrale zorg is een ander onderwerp dat centraal staat binnen mijn leerstoel. Zoals de beroemde Rorschach test, de beroemde inktvlekkentest, heeft integrale zorg vele betekenissen. Een bekende definitie van integrale zorg is die van van Raak: "Integrale zorg betreft een samenhangend en gecoördineerd pakket van diensten die worden gepland, gemanaged en geleverd aan individuele thuiswonende 
zorggebruikers door een scala van organisaties en professionals. Het omvat het hele spectrum van gezondheidszorg en welzijn: medische zorg, thuiszorg, informele zorg, sociale ondersteuning, huisvesting en openbaar vervoer. Doel is die diensten te verlenen die de vrager nodig heeft, op de goede plaats en juiste tijd". Het gaat hier om zorg op maat. Het gaat vaak om een zorgpad of een zorgketen gericht op de individuele behoeften van de patiënt, waarbij alle hulpverleners, al dan niet uit verschillende sectoren of van verschillende organisaties, hun activiteiten zo veel mogelijk op elkaar afstemmen, zodat een samenhangend aanbod van zorg rondom de patiënt ontstaat.

Door hun aard en karakter verschillen publieke gezondheid en integrale zorg van de zorg die wordt geboden in de medische curatieve sector. Publieke gezondheid en integrale zorg zijn meer gericht op de patiënt. Omdat het vaak gaat om een samenwerking tussen meerdere groepen hulpverleners zijn coördinatie, afstemming en samenwerking tussen hulpverleners van groot belang. 


\section{Health Technology Assessment en economische evaluatiestudies}

\subsection{Inleiding}

$\mathrm{Nu}$ ik jullie wat meer inzicht heb gegeven in het vakgebied waarin ik voornamelijk onderzoek doe, de publieke gezondheid en de integrale zorg, wil ik jullie nu wat meer vertellen over het soort onderzoek dat ik doe, oftewel het vakgebied van "Health Technology Assessment". En dit vakgebied is minder moeilijk, dan dat het op het eerste gezicht lijkt. Stel dat je afgelopen december aan de Kerstman een tablet hebt gevraagd. Het is altijd fijn als de Kerstman ${ }^{1}$ precies weet wat je wilt hebben. Dus voordat je jouw lijstje opstelt ga je je eerst oriënteren, welke merk en model tablet je wilt vragen.

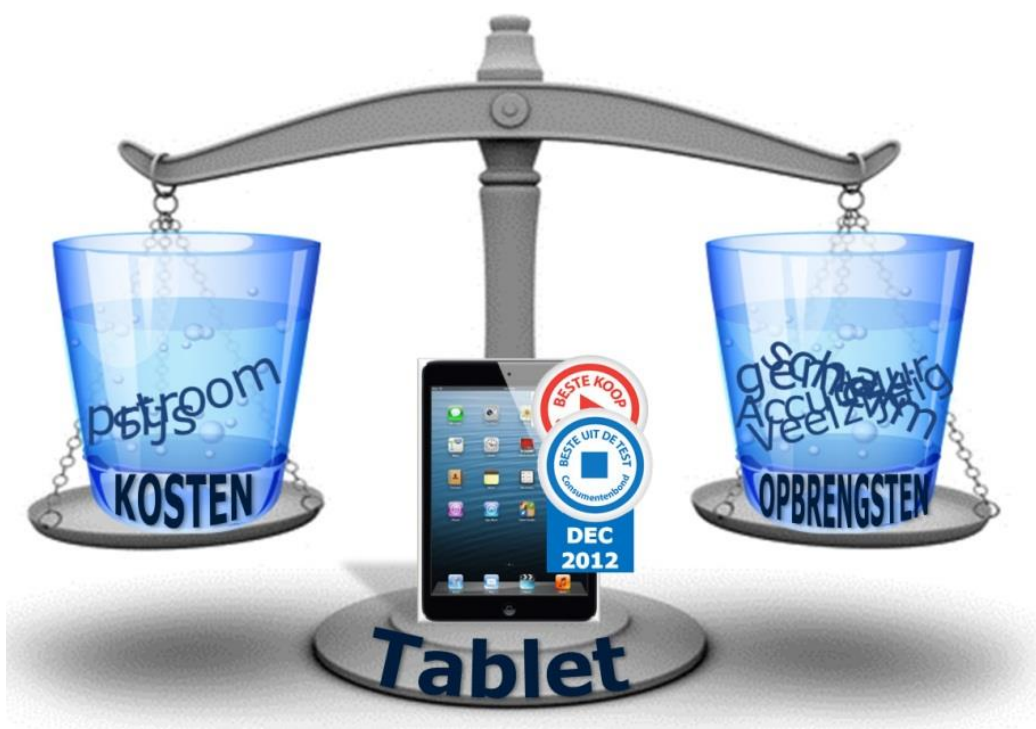

Figuur 1 Afweging kosten en opbrengsten tablet

Je vraagt informatie bij je vrienden en collega's, je leest krantenartikelen over tablets, je bekijkt tests in de consumentengids en je let daarbij bijvoorbeeld op de kosten voor de Kerstman, maar ook op de kosten die je zelf gaat maken in verband

\footnotetext{
${ }^{1}$ Gezien het aanwezige publiek wordt bij deze oratie als uitgangspunt genomen dat de Kerstman bestaat $;-)$.
} 
met stroomgebruik. Daarnaast let je ook op het gebruiksgemak, de kwaliteit van het scherm, de veelzijdigheid en de accuduur. Je weegt als het ware de kosten en opbrengsten van de verschillende tablets tegen elkaar af en beslist dan vervolgens welke tablet voor jou het beste is.

Misschien heb je in diezelfde periode ook gekeken naar een nieuwe zorgverzekering voor 2013. Als je daarin een keuze hebt gemaakt, heb je ook de kosten en opbrengsten van de verschillende zorgverzekeringen bekeken en deze tegen elkaar afgewogen. Je hebt bijvoorbeeld aan de kostenkant gekeken naar de maandelijkse premie, maar ook naar de hoogte van het eigen risico, vervolgens heb je gekeken of je alleen een basisverzekering wilt of ook een aanvullende verzekering. Als je kiest voor een aanvullende verzekering, heb je vervolgens ook bekeken wat wordt vergoed: brillen en lenzen, meer behandelingen voor de fysiotherapie, medische hulp in het buitenland, bepaalde medicijnen, psychologische hulp, orthodontie, alternatieve geneeswijzen, enzovoorts. Daarnaast heb je al dan niet een keuze gemaakt voor een tandartsverzekering. Je weegt hier ook weer de kosten en opbrengsten van de verschillende zorgverzekeringen tegen elkaar af, maar je kijkt hierbij naar andere aspecten dan bij de aanschaf van een tablet.

Belangrijk voor de rest van mijn oratie is, dat het duidelijk is dat voor iedere keuze, weer andere aspecten van belang zijn. Voor de tablet kijk je bijvoorbeeld aan de kostenkant naar de prijs van de tablet en stroomgebruik. Aan de opbrengstenkant kijk je naar gebruiksgemak, kwaliteit van het scherm, veelzijdigheid en accuduur. Bij de keuze voor de zorgverzekering kijk je naar hele andere aspecten. Aan de kostenkant kijk je naar de maandelijkse premie, het eigen risico, de kortingen en de kosten van een aanvullende verzekering. Bij de opbrengsten kijk je naar de dekking van allerlei behandelingen en eventueel het afsluiten van een tandartsverzekering.

$\mathrm{Nu}$ wil ik jullie iets meer vertellen over het vakgebied "Health Technology Assessment" en meer in het bijzonder over economische evaluatiestudies. Economische evaluatiestudies richten zich ook op de afweging van kosten en opbrengsten, maar dan in de zorg. We kijken naar nieuwe behandelingen in de zorg en vergelijken deze dan met bestaande behandelingen, ook wel gebruikelijke zorg genoemd. We bekijken de kosten en opbrengsten vanuit een maatschappelijk perspectief, dus naar de consequenties van het invoeren van een behandeling op de Nederlandse samenleving, bijvoorbeeld of het verstandig is om een bepaald geneesmiddel te vergoeden via de basisverzekering. Bij deze vergelijking 
onderzoeken we hoeveel een nieuwe behandeling kost, maar ook kijken we naar de kosten van de zorg die de patiënt daarnaast gebruikt, bijvoorbeeld een bezoek aan de huisarts. Daarnaast onderzoeken we ook welke invloed deze behandeling heeft op het hervatten van werk. Verder kijken we of het beter gaat met de gezondheid van de patiënt en hoe een betere gezondheid van invloed is op zijn of haar kwaliteit van leven.

Het wetenschapsgebied, dat zich bezighoudt met de informatie die besluitvormers nodig hebben bij de afweging van verschillende behandelingen, is "Health (voorheen Medical) Technology Assessment" (HTA). Bij HTA gaat het om een "gestructureerde analyse van een aantal aspecten van een nieuwe of bestaande behandeling met als doel informatie te krijgen over de invloed en de stand van de wetenschap, om zo een beleidsbeslissing te kunnen ondersteunen". HTA is een synthesewetenschap, een wetenschap waarbij kennis vanuit verschillende disciplines - onder andere geneeskunde, economie, psychologie, epidemiologie, etc.- bij elkaar worden gebracht om te komen tot een afgewogen beslissing. ledere behandeling kan onderwerp zijn van een HTA studie, het kan gaan om een geneesmiddel, een operatie, maar ook om voorlichting, psycho-educatie, of een organisatieverandering.

Economisch evaluatieonderzoek is een deelgebied binnen HTA. Bij economisch evaluatieonderzoek gaat het om een vergelijking tussen twee of meer behandelingen, waarbij de kosten worden gerelateerd aan de opbrengsten van die twee of meer behandelingen.

Binnen economisch evaluatieonderzoek wordt verondersteld, dat de belangrijkste stakeholders (i.c. behandelaars, patiënten, zorgverzekeraars en de overheid) binnen de zorg allemaal hun eigen doelstelling hebben en dat deze stakeholders rationele keuzes maken om deze doelstellingen te bereiken. $\mathrm{Om}$ een rationele keuze te kunnen maken moeten altijd twee of meer behandelingen tegen elkaar worden afgewogen, waarbij een systematische analyse wordt uitgevoerd van de kosten en de opbrengsten.

Sinds een aantal decennia wordt het als belangrijk gezien dat niet alleen wordt gekeken naar hoe goed behandelingen zijn, dus of mensen beter worden, maar ook dat gekeken wordt naar de kosteneffectiviteit; krijgen we de beste zorg voor de beste prijs. De toegenomen belangstelling voor kosten en opbrengsten van behandelingen heeft een aantal oorzaken. Aan de ene kant zijn de uitgaven voor de zorg gedurende de afgelopen jaren toegenomen en wordt een nog sterkere groei 
verwacht gedurende de komende decennia. Als gevolg van de toenemende uitgaven, tracht de overheid de kosten van de zorg steeds meer te controleren. Aan de andere kant groeit de omvang van het aantal mogelijke behandelingen. Dit geldt zeker ook voor behandelingen op het gebied van publieke gezondheid en integrale zorg. Steeds meer behandelingen worden aangeboden, omdat steeds meer mogelijk is. Omdat de beschikbare financiën voor de zorg echter beperkt zijn, ontstaat schaarste. Een gevolg van schaarste is, dat keuzes moeten worden gemaakt. Deze keuzes vinden op allerlei niveaus plaats. Op nationaal niveau beslist de overheid bijvoorbeeld welke verrichtingen opgenomen worden in het basispakket, en dus vergoed worden voor alle Nederlanders. Informatie over de kosteneffectiviteit wordt steeds belangrijker bij deze beslissing. Zo is recent te lezen in het regeerakkoord, dat het kabinet Rutte-Asscher voorstelt, om het criterium kosteneffectiviteit wettelijk te verankeren in de Zorgverzekeringswet om daarmee te komen tot een beter beheer van het basispakket. 


\section{Drie Mythes over (Public) Health Technology Assessment}

Voordat ik verder inga op de specifieke kenmerken van "Public Health Technology Assessment" wil ik graag drie mythes die bestaan over HTA/economische evaluaties met jullie bespreken; te weten;

- Mythe 1: Het gaat alleen maar om geld

- Mythe 2: Mijn behandeling is goedkoper, dus is het zeker kosteneffectief

- Mythe 3: Prioriteiten stellen: eerst effectonderzoek en dan economische evaluatieonderzoek

\subsection{Mythe 1: Het gaat alleen maar om geld}

De eerste mythe die ik hier wil bespreken, is dat gezondheidseconomen en HTA onderzoekers slechts geïnteresseerd zijn in de zogenaamde "geldkant", de kostenkant. Het is nu uit het balanceren van de 2 glazen op de weegschaal wellicht duidelijk dat in ons onderzoek de afweging tussen kosten en opbrengsten een belangrijke rol speelt. En als ik eerlijk ben, gaat veel van ons onderzoek in op de vraag hoe we uitkomsten het beste kunnen meten, de opbrengstenkant dus. Het belangrijkste uitgangspunt bij HTA onderzoek is het informeren van beleidsmakers op zowel lokaal als nationaal niveau. Omdat beleidsmakers vaak keuzes moeten maken tussen behandelingen bij verschillende klachten en aandoeningen zijn we op zoek naar generieke, algemene, uitkomstmaten; vragenlijsten die bij iedereen afgenomen kunnen worden. Daarnaast zijn we geïnteresseerd in de voorkeuren, in de preferenties van de individuele deelnemer, die we dan vaak uitdrukken in utiliteiten gerelateerd aan kwaliteit van leven. De maat "kwaliteit van leven" is al het ware onze "heilige graal". Bij effectmeting gebruiken we vaak gestandaardiseerde instrumenten, die in de medisch curatieve sector zijn ontwikkeld om kwaliteit van leven vast te stellen. Een veel gebruikt instrument om kwaliteit van leven te meten is de EuroQol.

Dit is een generiek instrument dat iedereen kan invullen en waarmee de kwaliteit van leven gemeten kan worden. Je kunt dit instrument als het ware nu, terwijl je in de zaal zit invullen. De EuroQol belicht vijf aspecten van kwaliteit van leven, te weten mobiliteit (problemen met lopen); zelfzorg (problemen met wassen of aankleden); dagelijkse activiteiten (bijvoorbeeld problemen met werk, studie, 
huishouden, gezins- en vrijetijdsactiviteiten), pijn en andere klachten en ten slotte stemming (de vraag of je niet angstig of somber bent). In de meest gebruikte versie tot nu toe staan bij ieder aspect drie antwoordmogelijkheden ${ }^{2}$ vermeld, te weten ik heb geen problemen met dit aspect, ik heb enige problemen met dit aspect en ik heb heel veel problemen met dit aspect. In het voorbeeld is de EuroQol ingevuld door iemand met een depressie. ${ }^{3}$ In dit geval heeft hij of zij geen problemen met mobiliteit, geen problemen met zelfzorg, enige problemen met dagelijkse activiteiten, geen pijn of andere klachten en is hij of zij ernstig depressief. Dit is een eenvoudige manier om kwaliteit van leven te meten. Veel van ons onderzoek richt zich op het beter meten van de opbrengstenkant van de weegschaal. Onderzoek naar de opbrengsten, oftewel uitkomstonderzoek, vormt de kern van het HTA onderzoek en het is zeker niet "all about the money".

\subsection{Mythe 2: Mijn behandeling is goedkoper dus het is zeker kosteneffectief}

Het gebeurt wel een paar keer per jaar dat een enthousiaste hulpverlener bij ons binnenstormt met de mededeling: mijn behandeling is goedkoper, dus het is zeker kosteneffectief. En om deze mythe uit de weg te helpen is het van belang om te weten dat de kosten van de behandeling slechts een heel klein deel zijn van de totale kosten, die we meenemen in een economische evaluatiestudie. We kijken bij een economische evaluatiestudie in het bijzonder naar de impact die een behandeling, heeft op de maatschappij aan de kostenkant van onze weegschaal. Dit betekent, dat wij niet alleen kijken naar de kosten van de behandeling die wordt onderzocht, maar ook naar alle andere kosten die relevant zijn voor de maatschappij.

Je kunt daarbij denken aan alle andere behandelingen, die een patiënt ondergaat om gezond te worden, bijvoorbeeld bezoek aan de huisarts, opname in het ziekenhuis, bezoek aan de GGD of revalidatiecentrum. Maar ook aan kosten die familie en vrienden maken om de patiënt te bezoeken en aan de mantelzorg of informele zorg die patiënten ontvangen. Of allerlei geneesmiddelen en dergelijke die mensen zelf bij een DA-vestiging of het Kruidvat kopen om gezond te worden. Of het feit dat iemand wel of niet het huishouden kan doen, naar school kan gaan,

\footnotetext{
${ }^{2}$ Dit is de EQ-5D-3L. Recent is een versie ontwikkeld met 5 antwoordmogelijkheden EQ-5D-5L, waarvoor ook een utiliteitstarief wordt ontwikkeld.

${ }^{3}$ Dit gezondheidsprofiel kan met behulp van een formule (ook wel tarief genoemd) omgezet worden in utiliteiten, hiervoor bestaat een Nederlandse tarief [ref], maar ook een Engelse tarief [ref].
} 
of kan werken. Daarnaast berekenen we de doorlopende kosten, we meten met andere woorden de kosten continue [ref*]; dit betekent dat indien we een patiënt tijdens 1 jaar voor wetenschappelijk onderzoek volgen, dat alle kosten en uitgaven die de patiënt, zijn omgeving en de maatschappij maakt berekend en meegenomen worden in het onderzoek.

Wat we dus doen is dat we kijken naar alle kosten voor de maatschappij en wegen die af tegen de opbrengsten. Aan de kostenkant kijken we naar de kosten van de behandeling, gezondheidszorgkosten, kosten voor de patiënt en zijn omgeving en participatie, bijvoorbeeld productiviteitsverlies. Bij de opbrengstenkant kijken we naar gezondheid en kwaliteit van leven. Een behandeling kan op zichzelf goedkoper zijn dan de gebruikelijke zorg, maar de kosten voor de maatschappij kunnen hoger zijn omdat de patiënt naast de onderzochte behandeling allerlei andere zorg gaat gebruiken of zaken gaat aanschaffen.

\subsection{Mythe 3: Prioriteiten stellen, eerst effectonderzoek, dan economische evaluatieonderzoek}

Zoals ik jullie eerder heb laten zien gaat het bij economisch evaluatieonderzoek om de afweging tussen kosten en opbrengsten. We vergelijken altijd twee interventies, meestal een nieuwe behandeling en de gebruikelijke zorg. We kijken eigenlijk naar twee weegschalen; een kostenweegschaal en een opbrengstenweegschaal, waarbij we de kosten en opbrengsten van de nieuwe behandeling en gebruikelijke zorg tegen elkaar afwegen. Binnen dit onderzoek zijn vier soorten uitkomsten mogelijk (zie figuur 2a). Allereerst kan het zijn dat de nieuwe behandeling minder kost dan de gebruikelijke zorg, terwijl de nieuwe behandeling meer effecten oplevert dan gebruikelijke zorg. De nieuwe behandeling is dus goedkoper en beter dan de gebruikelijke zorg. Dit is de meest gunstige uitkomst voor een nieuwe behandeling (zuidoostelijk kwadrant figuur 2a). Beleidsmakers zullen over het algemeen op grond van de resultaten, de behandeling gelijk invoeren. 


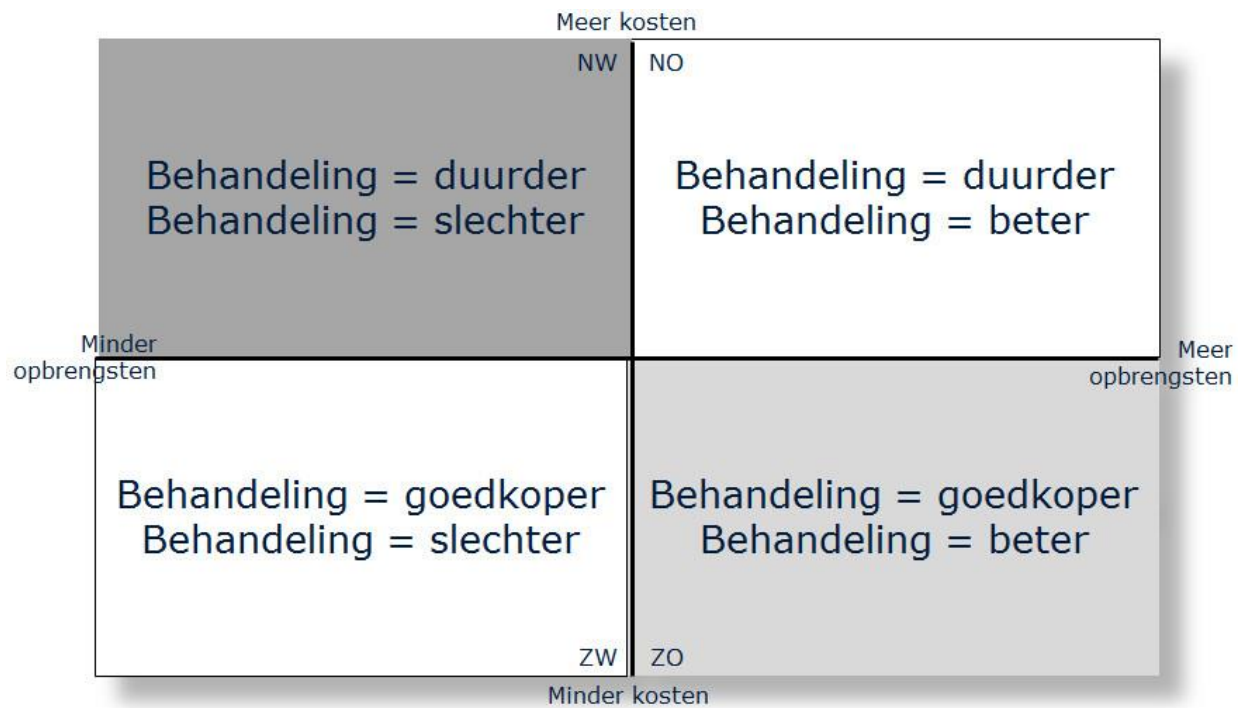

Figuur 2a Mogelijke uitkomsten economische evaluatie studie

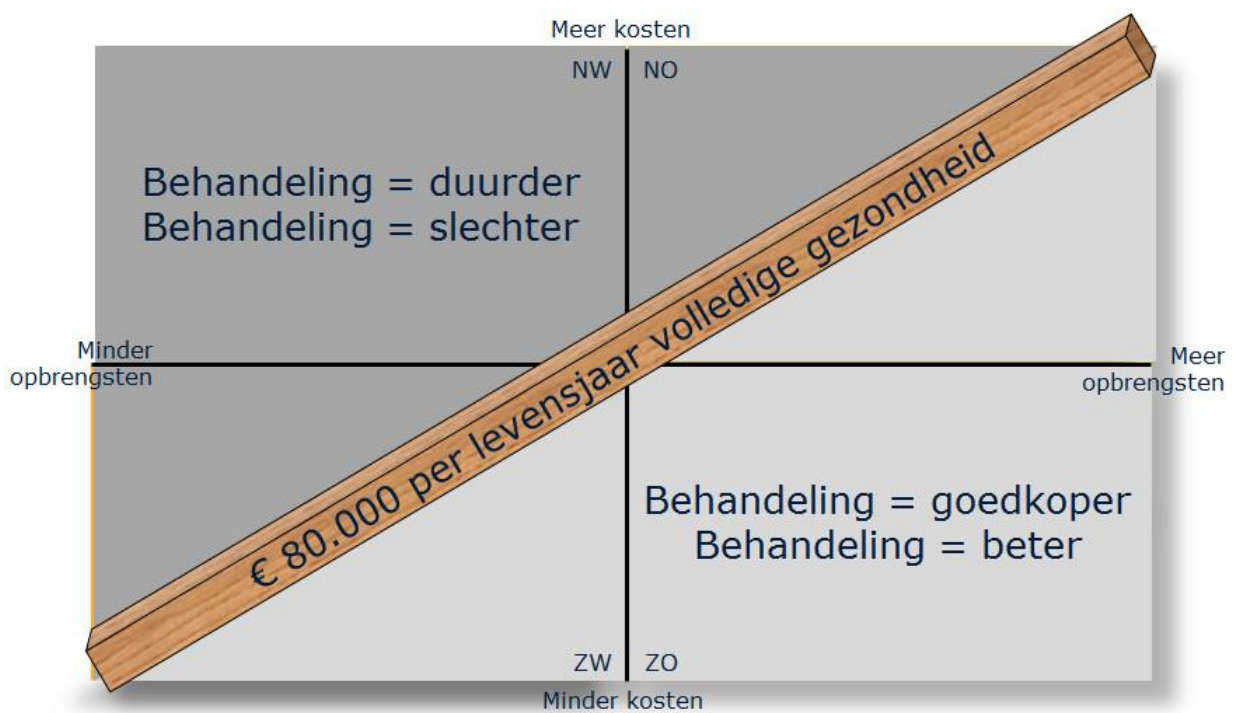

Figuur 2b Mogelijke uitkomsten economische evaluatie studie

In het andere uiterste geval kan het zo zijn dat de nieuwe behandeling meer kost dan de gebruikelijke zorg, terwijl de nieuwe interventie minder effecten oplevert dan gebruikelijke zorg. De nieuwe behandeling is dan dus duurder en slechter dan 
de gebruikelijke zorg (noordwestelijk kwadrant figuur 2a). Indien dit de uitkomst is van onze studie, zullen beleidsmakers de nieuwe behandeling niet invoeren.

In de meeste gevallen is de nieuwe behandeling duurder, maar levert ze ook meer effecten op in vergelijking met gebruikelijke zorg (noordoostelijk kwadrant figuur 2a). En soms kost de nieuwe behandeling minder, maar levert ze ook minder effecten op. In deze gevallen is het minder duidelijk wat je moet doen (zuidwestelijk kwadrant figuur 2a).

Indien de uitkomsten van economisch evaluatieonderzoek vallen in het lichgrijze of het donkergrijze vlak dan is het overduidelijk wat we een beleidsmaker moeten adviseren.

In de overige vlakken (noordoostelijk en zuidwestelijk kwadrant figuur 2a) zijn de adviezen aan de beleidsmakers moeilijker te geven. Het kan betekenen dat de nieuwe behandeling duurder is, maar beter in opbrengsten (noordoostelijk kwadrant figuur 2a), of goedkoper, maar slechter in opbrengsten (zuidwestelijk kwadrant figuur $2 \mathrm{a})$.

Om keuzes te vergemakkelijken in het witte vlak, kun je in dit vlak een lat leggen. Die lat bepaalt wanneer de kosten te hoog zijn in relatie tot de opbrengst van de behandeling (zie figuur 2b). Om beslissingen te vergemakkelijken in de witte vlakken, heeft de Raad voor de Volksgezondheid en Zorg, de RVZ, voor Nederland, zo'n lat, zo'n grenswaarde, bepaald. De RVZ denkt dat een grens van $€ 80.000$,- per gewonnen levensjaar in volledige gezondheid ${ }^{4}$ reëel is. Door het toepassen van de grenswaarde van $€ 80.000$,- "per gewonnen levensjaar in volledige gezondheid" wordt een deel van de witte vlakken of lichtgrijs ...of donkergrijs... . Voor het vlak rechtsboven betekent dit, dat een behandeling die ondanks dat ze duurder is dan gebruikelijk zorg, ook kosteneffectief is, indien de behandeling valt in het groene vlak, indien de extra kosten niet hoger zijn $€ 80.000$,- "per gewonnen levensjaar in volledige gezondheid" zijn.

Bovendien word ik persoonlijk iedere keer heel erg verdrietig als ik weer zie dat een onderzoek, een trial wordt opgezet waarbij alleen wordt gekeken naar de opbrengsten. Waarom blijven veel onderzoekers navelstaren naar de ene kant, de opbrengstenkant, van de weegschaal? Het opzetten van een onderzoek is duur en

\footnotetext{
${ }^{4}$ In vaktermen gaat het om 1 Quality Adjusted Life Year, 1 QALY staat voor 1 jaar in volledige gezondheid
} 
kost veel gemeenschapsgeld. Het vergt relatief weinig extra inspanningen om bij een onderzoek óók te kijken naar de kosteneffectiviteit, naast een effectiviteitsevaluatie en een procesevaluatie. In vakjargon, de marginale kosten van het meenemen van een economische evaluatiestudie bij een effectstudie zijn gering, terwijl de opbrengsten in wetenschappelijke en beleidszin groot zijn. Zoals ik eerder heb laten zien wordt het steeds moeilijker om beleidsmakers alleen te overtuigen met de resultaten van een effectstudie. Op lokaal, regionaal en nationaal niveau, alsook in de wetenschap is het besef doorgedrongen, dat we naar de kosten en effectenkant moeten kijken bij het implementeren van een behandeling, net zoals jullie zelf al doen bij het kopen van een tablet of het uitzoeken van een zorgverzekering. En als je economisch evaluatieonderzoek gaat doen, doe het dan serieus. Ga niet zelf hobbyen. In ieder academisch centrum is de kennis en ervaring en de wilskracht om een goede economische evaluatiestudie op te zetten. De bal ligt bij jullie. Maar het is een mythe om eerst effectonderzoek te doen en dan economische evaluatieonderzoek.

Of in eigentijdse termen "Uitkomstonderzoek zonder HTA is zóóó 2012!" Ik kom hier zeker nog op terug...

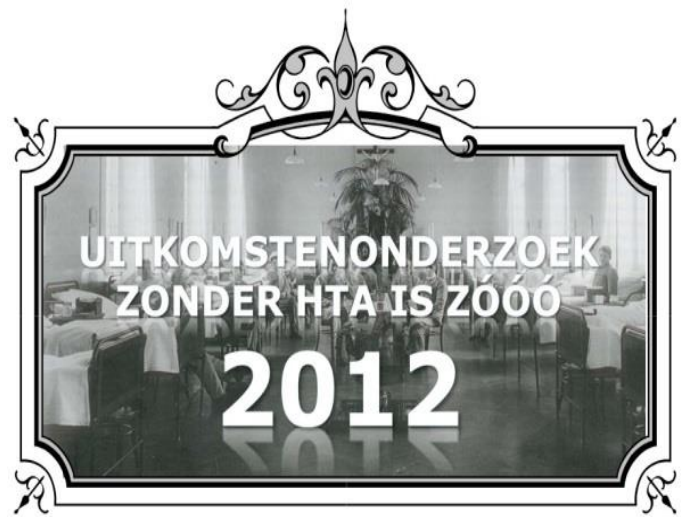

Figuur 3 Gasthuis Calvariënberg, ca. 1900, voorloper azM/MUMC+ 


\section{Public Health Technology Assessment: niet horen, niet zien en zwijgen!}

Het probleem met het onderzoek dat ik doe is dat HTA en economisch evaluatieonderzoek zijn ontstaan vanuit de medische curatieve sector. De technieken en methoden die we nu gebruiken zijn in een medische setting ontwikkeld en verfijnd. We gebruiken nu dezelfde methodieken voor onderzoek naar medische curatieve interventies, als voor interventies in de publieke gezondheid en integrale zorg. Naar analogie van de keuze van een tablet en de keuze van een zorgverzekering gebruiken we, als HTA-onderzoekers, niet zoals ik eerder deed in de oratie verschillende criteria (voor tablet en zorgverzekering), maar dezelfde criteria bij de keuze voor een behandeling in medisch-curatieve zorg, als voor de keuze voor een interventie in de publieke gezondheid en de integrale zorg. Dat komt omdat we vaak nog niet zien hoe anders publieke gezondheid en integrale zorg zijn en ook niet goed luisteren naar wat de patiënten en hulpverleners in de publieke gezondheid en de integrale zorg nu echt beweegt. Het komt ook in toenemende mate voor dat we die verschillen wel zien en horen, maar dat we dezelfde methodes blijven toepassen bij de publieke gezondheid en de integrale zorg als bij puur medische curatieve behandelingen. We zwijgen dan over de lacunes die onze HTA onderzoeksmethodes hebben bij de toepassing op de publieke gezondheid en de integrale zorg: ....Public Health Technology Assessment: niet horen, niet zien en zwijgen! Om een eerlijke vergelijking tussen de medisch curatieve sector, de publieke gezondheid en integrale zorg mogelijk te maken op het gebied van HTA, moeten we naar andere criteria die kosten en opbrengsten van al deze zorggebieden goed kunnen identificeren, meten en waarderen. 


\section{Methodologische uitdagingen voor Public Health Technology Assessment: horen, zien en niet zwijgen!}

Zoals ik hiervoor heb aangegeven, is het raamwerk van "Health Technology Assessment" ontwikkeld binnen de medische curatieve sector en werd dit HTA raamwerk tot voor kort zonder enige aanpassingen toegepast binnen de onderzoeksgebieden van de publieke gezondheid en de integrale zorg. Op weg naar: horen, zien en niet zwijgen!, had ik jullie graag een compleet overzicht willen geven van de belangrijkste methodologische uitdagingen voor HTA binnen het vakgebied van publieke gezondheid en integrale zorg. Helaas is dit overzicht te omvangrijk en lukt het mij niet om binnen de duur van deze oratie, alle methodologische uitdagingen en mogelijke oplossingen met jullie te delen. In tabel 1 vinden jullie een overzicht van de belangrijkste uitdagingen.

-Tabel 1 ongeveer hier (volgt nog)-

Wat betreft de oplossingen is niet zo dat we van nul starten, in Maastricht maar ook in de rest van Nederland wordt al hard gewerkt aan nieuwe methodologieën voor HTA studies. In het volgende deel van mijn oratie zal ik mij beperken tot drie methodologische problemen, waar ik in Maastricht samen met andere collega's aan verder werk.

\subsection{Kosten en opbrengsten buiten de gezondheidszorg}

Als eerste wil ik aandacht besteden aan het identificeren, meten en waarderen van de kosten en opbrengsten buiten de medische curatieve sector. Interventies op het gebied van integrale zorg en publieke gezondheid leveren een substantiële bijdrage aan de maatschappij als geheel, bijvoorbeeld als iemand gezonder is; kan hij meedoen aan de samenleving en bijvoorbeeld gaan werken. Veel behandelingen binnen de publieke gezondheid hebben ook gevolgen voor andere sectoren, denk bijvoorbeeld aan de invloed van gezondheid op deelgebieden als sociale zaken en werkgelegenheid, onderwijs en justitie. Daarnaast is het ook belangrijk dat interventies in de publieke gezondheid en de integrale zorg ook positieve effecten hebben voor een bredere populatie dan de deelnemer zelf, bijvoorbeeld op 
familieleden, buren en vrienden en collega's. Voorbeelden zijn dat wanneer iemand gezond gaat eten, dit ook van invloed is op zijn of haar gezin. Als iemand gaat rennen, dat zij haar buurvrouw meeneemt. Of als iemand op je werk stopt met roken, één van de collega's ook besluit om te stoppen met roken. Daarnaast richten interventies in de publieke gezondheid zich in toenemende mate op de gemeenschap en niet op het individu alleen. Als gevolg hiervan vallen - in tegenstelling tot medische curatieve behandelingen, waarbij de kosten en opbrengsten in de gezondheidszorg liggen - de opbrengsten en kosten van interventies van publieke gezondheid en integrale zorg vaak buiten de gezondheidszorg, in andere sectoren. Daarnaast wordt de gezondheidzorg in het algemeen, en publieke gezondheid in het bijzonder, beïnvloed door investeringen buiten de gezondheidszorg. Zo is bijvoorbeeld de woonomgeving van invloed op ons beweeggedrag. Onderzoek heeft uitgewezen, dat door de aanwezigheid van sport en speelruimtes het beweeggedrag van volwassenen en kinderen wordt beïnvloed. Dit noemen we externaliteiten, externe effecten of externe kosten. Het is moeilijk om deze externe effecten goed mee te nemen in een economische evaluatiestudie.

Momenteel lopen een aantal projecten binnen het HTA programma Maastricht die meer inzicht verschaffen in de kosten en de baten buiten de medische sector. De invloed van gezondheid op arbeidsparticipatie staat centraal in een studie die we samen met Cindy Noben, Angelique de Rijk en Frans Nijhuis uitvoeren. Daarnaast wordt de wisselwerking tussen zorggebruik in de geestelijke gezondheidszorg en lichamelijke aandoening bij een beroerte in het $€$-RESTORE project samen met Mitchel van Eeden en Caroline van Heugten onderzocht. Bij het $€$-RESTORE project kijken we eveneens naar de relatie tussen de deelnemers en hun informele zorgverleners. Samen met de Wereldgezondheidszorgorganisatie kijken we naar de externe effecten van vaccinaties. In dit project, dat ik samen met Inge van der Putten uitvoer, werken we nauw samen met Raymond Hutubessy. Op een meer fundamentele manier kijk ik samen met Ruben Drost, Aggie Paulus en Dirk Ruwaard naar de intersectorale kosten en baten van preventie in een project gefinancierd door ZonMw. 


\subsection{Bredere uitkomstmaten; proces uitkomsten en uitkomsten naast gezondheid}

Zoals ik eerder liet zien wordt kwaliteit van leven in ons vakgebied vaak gemeten door middel van de EuroQoL, waarbij aandacht wordt besteed aan vijf aspecten van gezondheid te weten mobiliteit, zelfzorg, dagelijkse activiteiten, pijn en andere klachten, en stemming. Het probleem met het onderzoek op het gebied van publieke gezondheid en integrale zorg is dat de winst zich vaak uitstrekt buiten deze vijf aspecten van de EuroQoL en ook buiten het gebied van gezondheid gerelateerde kwaliteit van leven. Om kwaliteit van leven binnen de publieke gezondheid en integrale zorg goed te kunnen meten moeten we vragenlijsten ontwikkelen die een breed spectrum van aspecten beslaan. Voorbeelden van dergelijke aspecten zijn eigenwaarde, zelfvertrouwen, welbevinden en zelfredzaamheid. Daarnaast weten we uit onderzoek naar de voorkeuren van mensen bij leefstijlinterventies dat ook het proces, dus de manier waarop je die leefstijl interventies ondergaat, van invloed is op de uiteindelijke voorkeuren. Je kunnen hierbij denken aan hoe de leefstijlinterventie wordt aangeboden, moet je bijvoorbeeld alleen gaan sporten of in een groep, moet je veel reizen om aan de interventies deel te kunnen nemen, of het soort dieet iemand volgt, etc. Daarnaast weten we ook dat geloof in de behandeling en verwachtingen omtrent de behandeling de uiteindelijke uitkomst en dus de kwaliteit van leven zal beïnvloeden. Ten slotte, fluctueert iemands kwaliteit van leven over zijn ziekteperiode door bijvoorbeeld adaptatie. Samengevat, we weten nog te weinig over hoe we brede uitkomstmaten moeten meten in HTA. Om deze problemen op te lossen denken we momenteel aan verschillende mogelijkheden. Een oplossing is om meer aspecten mee te nemen als we kwaliteit van leven meten, naast de traditionele aspecten die worden meegenomen in de EuroQoL. Een andere manier om niet alleen te kijken naar wat deelnemers wel of niet meer kunnen, maar meer te kijken naar de capaciteiten van een deelnemer in navolging van de Nobelprijswinnaar Sen bijvoorbeeld in de ICEpop CAPability methode (ICECAP). De ICECAP; welke onder meer de volgende aspecten bevat: toewijding (liefde en vriendschap), veiligheid, onzekerheid over de toekomst), en rol-functioneren (doe je zaken waardoor je echt gewaardeerd wordt). Andere alternatieven zijn geluksindexen (bijvoorbeeld de Oxford Happiness Questionnaire), en instrumenten die welzijn meten (bijvoorbeeld de Warwick-Edinburgh Mental Well-being Scale (WEMWBS)) 
Ook op dit deelgebied wordt binnen het HTA programma van de onderzoeksschool CAPHRI hard gewerkt. Ik kan hier slechts een aantal studies noemen. Samen met Carmen Dirksen en Manuela Joore exploreren we allerlei methodes om kwaliteit van leven op een andere manier te meten. Met Mariëlle Goossens onderzoek ik al jaren de psychologische aspecten van kwaliteit van levenmeting. In het Supported Fast Track project van Ans Bouman onderzoeken we samen met Bea Hemmen en Henk Seelen naar hoe kwaliteit van leven over een lange tijd verandert bij mensen met een multi-trauma. En bij het ZonMw project An INstrument FOR outcome Measurement in Economic evaluations of Health promotion; het INFORMEH project inventariseer ik samen met Adriënne Alayli-Goebbels en Marie-Jeanne Aarts, het brede spectrum van uitkomstmaten bij gezondheidszorgpromotie en preventie.

\subsection{Kwaliteit van leven voor specifieke doelgroepen}

Ten slotte, wil ik als laatste methodologisch probleem aandacht vragen voor de kwaliteit van levenmeting bij specifieke doelgroepen. Hieronder vallen een aantal thema's. Effecten in de publieke gezondheid en integrale zorg worden vaak gemeten door gebruik te maken van surrogate effectmaten, voornamelijk intermediaire uitkomstmaten en ziekte specifieke uitkomstmaten. Intermediaire uitkomstmaten geven een indicatie of het klinisch beter met iemand gaat zoals de Body Mass Index bij overgewicht, of door te kijken of een bepaald gedrag is veranderd, zoals stoppen met roken. Bij ziekte specifieke uitkomstmaten wordt het voorkomen van een bepaalde ziekte of aandoening gemeten, bijvoorbeeld de Beck Depression Inventory bij depressie. Zoals ik al eerder aangaf zijn we uiteindelijk geïnteresseerd in generieke maten, zoals kwaliteit van leven of welzijn. Op dit moment hebben we nog te weinig kennis over de relatie tussen surrogate effectmaten en generieke effectmaten. De laatste jaren is daarnaast een continue punt van discussie of de uitkomstmeting bij economisch evaluatieonderzoek uitgevoerd moet worden door de deelnemer zelf of door de algemene bevolking. Beide methodes kennen voor- en nadelen, waardoor binnen HTA onderzoek nog steeds geen gestandaardiseerde methode zijn. Daarnaast blijkt uit onderzoek van Saskia Knies dat de waardering van de kwaliteit van leven zeer verschillend is in diverse landen in Europa, waardoor de data van economische evaluatiestudies wellicht niet gelden in andere landen. Verder is het van belang, te constateren dat de kosteneffectiviteit van interventies in de publieke gezondheid en de integrale zorg minder gunstig lijken voor deelnemers met een lage sociaaleconomische 
status in vergelijking met deelnemers met een hoge sociaaleconomische status; en voor allochtonen in vergelijking met autochtonen. Op dit moment hebben we te weinig inzicht in de kosteneffectiviteit van deze interventies bij specifieke doelgroepen. Meer onderzoek is nodig om inzicht te krijgen in de kosteneffectiviteit bij specifieke doelgroepen, zoals voor mensen met een lage sociaal economische status of voor mensen van een Turkse of Marokkaanse afkomst.

Veel onderzoek is de afgelopen jaren uitgevoerd naar de relatie tussen specifieke doelgroepen en kwaliteit van leven. Zo hebben de promotiestudies van Sylvia Gerhards en Karianne Jonkers samen met Marcus Huibers en Jacques van Eijk gekeken naar de relatie tussen depressiematen en generieke kwaliteit van leven. In de onderzoekstrajecten van Reina de Kinderen en Loes Leenen, exploreren we samen met onder andere Debby van Helvoort-Postulart en Marian Majoie diezelfde relatie bij mensen met epilepsie. Op een andere manier kijken we naar preferenties bij epilepsie onder andere met Ben Wijnen, Brigitte Essers en Mickael Hiligsmann. Met de data uit het promotietrajecten van Lotte Bamelis en Thea van Asselt zijn we van plan om samen met Arnoud Arntz en Pim Wetzelaer onderzoek op het zetten over de kwaliteit van levenmeting bij persoonlijkheidsstoornissen. Ten slotte, kwaliteit van leven bij mensen met een beroerte is een thema bij de studie van Ron Heijnen, dat samen met Trudy van de Weijden, Jos Schols en Martien Limburg wordt uitgevoerd.

Verder heb ik samen met Hans Bosma concrete plannen ontwikkeld om te kijken naar de relatie tussen kosteneffectiviteit en sociaal economische status. Als laatste, hebben we samen met het Trimbos instituut, met Filip Smit, plannen ontwikkeld om specifiek te kijken naar de kosteneffectiviteit van internetinterventies voor mensen van Turkse of Marokkaanse afkomst.

\subsection{Public Health Technology Assessment: te weinig data beschikbaar}

Naast de methodologische uitdagingen is het voor mijn vakgebied een groot probleem dat weinig HTA of economische evaluatiestudies zijn gedaan naar interventies binnen de publieke gezondheid en de integrale zorg. Kennis en inzicht in de kosteneffectiviteit van deze interventies ontbreekt vaak. Zoals ik al eerder heb aangegeven is informatie over kosteneffectiviteit een belangrijke voorwaarde 
voor de implementatie en financiering van deze interventies in de praktijk. Dit is in het bijzonder een complicerende factor, die we nu tegenkomen in de projecten van Nathalie Janssen en Caroline Wyers, vooral omdat we een deel van ons onderzoek daar graag zouden baseren op bestaande evidentie. Het is dan ook des te schrijnender dat de overheid in toenemende mate besluit om financiering van onderzoek over HTA-methodologie en van interventies in de publieke gezondheid te beperken.

Binnen Maastricht kijk ik samen met andere onderzoekers naar de kosteneffectiviteit van interventies op het gebied van publieke gezondheid en integrale zorg. Met Andrea Grauvogl, Jacques van Lankveld en Madelon Peeters kijken we naar de kosteneffectiviteit van seksuele counseling bij jongeren. Met Marijn de Bruin en Edwin Oberjé kijk ik naar de kosteneffectiviteit van medicatietrouw bij HIV patiënten. Met Henny Wansink en Clemens Hosman kijken we naar de kosteneffectiviteit van interventies bij KOPP-kinderen. De kosteneffectiviteit van "Praten met kinderen" bij een AMK wordt onderzocht in het promotietraject van Froukje Unger, dat ik samen met Cees Hoefnagels en Francien Lamers uitvoer. Daarnaast lopen op dit moment een aantal kosteneffectiviteit studies naar "stoppen met roken interventies" en "bewegen", onder ander met Eline Smit, Nadine Berndt, Hein de Vries, Lilian Lechner, Catherine Bolman, Ciska Hoving, Marike Hendriks en Hans Savelberg. 


\section{Horen, zien en niet meer zwijgen: voor onderwijs en management}

Het uitvoeren van onderzoek is slechts één van de vele taken van de universiteit. Voor minimaal de helft van de tijd, zijn medewerkers, bezig met onderwijs en managementtaken. Mijn mantra; horen, zien en niet zwijgen!, geldt voor mij niet alleen voor het onderzoeksgebied van "Public Health Technology Assessment", maar ook voor deze andere aspecten van ons werk.

Waar voorheen vooral de onderwijstaken belangrijk waren is sinds een decennium of twee het belang van onderzoek in de activiteiten van universiteiten enorm toegenomen,. De internationale druk van "publish or perish" is ons allen niet vreemd. De druk om te presteren is groot, de concurrentie moordend en aanzien is afhankelijk van het aantal publicaties in wetenschappelijke tijdschriften met een hoge impactfactor. Als gevolg hiervan lijkt het aantal gevallen van wetenschapsfraude te groeien. Dat dit een geval is van "Horen, zien en niet zwijgen!", behoeft wellicht geen betoog.

Daarnaast is binnen Nederlands universiteiten, waaronder ook bij de Universiteit Maastricht gekozen voor een vorm waarbij onderwijs en onderzoek organisatorisch zijn ontkoppeld. Beiden hebben hun eigen School met hun eigen regels, eisen en directie. Het gevaar, dat hierin schuilt, is dat hier ook per School naar één kant van de weegschaal gekeken wordt, ofwel naar de onderzoekskant, ofwel naar de onderwijskant zonder rekening te houden met de andere kant. Ik hoop dat bestuurders in toenemende mate meer oog gaan krijgen voor het gevaar van deze disbalans. 


\section{Tot slot}

En dan nu echt als laatste hoewel volgens de Van Dale het woord hooglerares wel bestaat, wordt een vrouw in een toga altijd "gewoon" hoogleraar genoemd. Hoe komt dat? Figuur 4a laat zien dat het aandeel vrouwen afneemt met iedere stap in de wetenschappelijke loopbaan. Dus hoe hoger de functie, hoe kleiner de kans dat het een vrouw is. Nederland is een voorloper als het gaat om mijn vakgebied, de publieke gezondheid, de integrale zorg en de HTA.

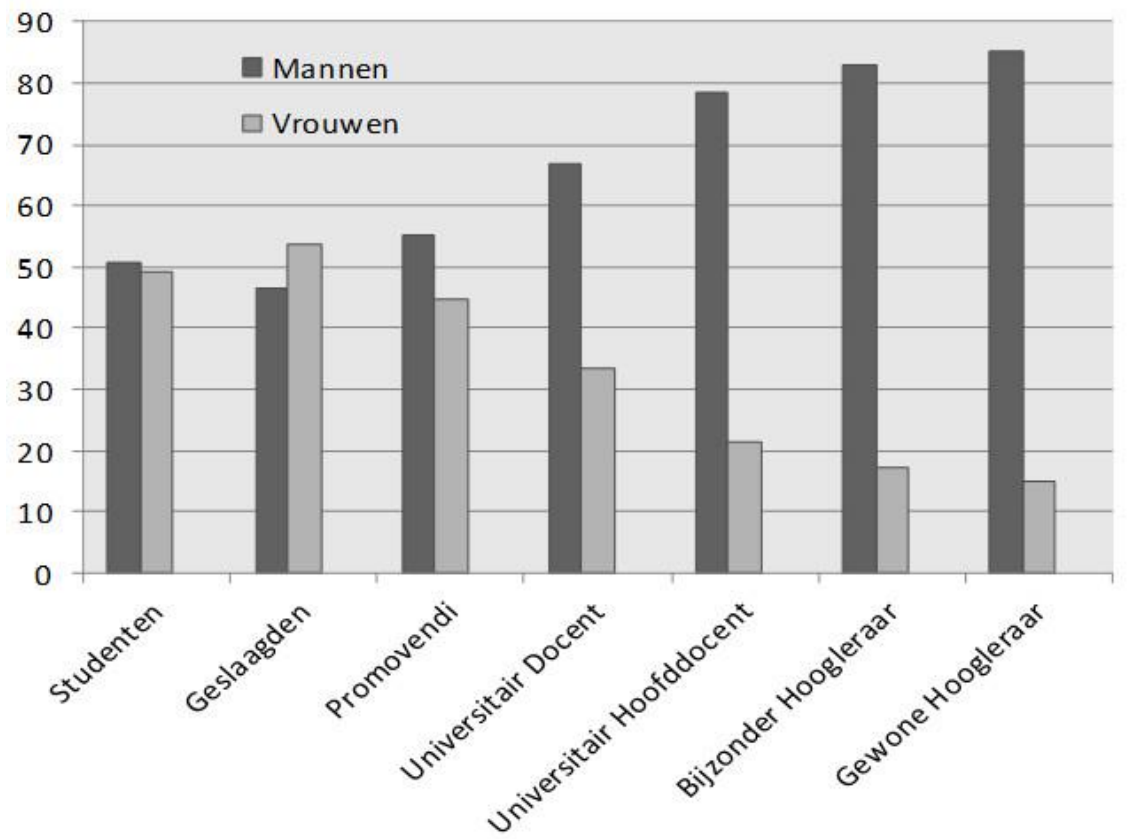

Figuur 4a Aandeel van vrouwelijke hoogleraren in 2011

Bron: Monitor Vrouwelijke Hoogleraren 


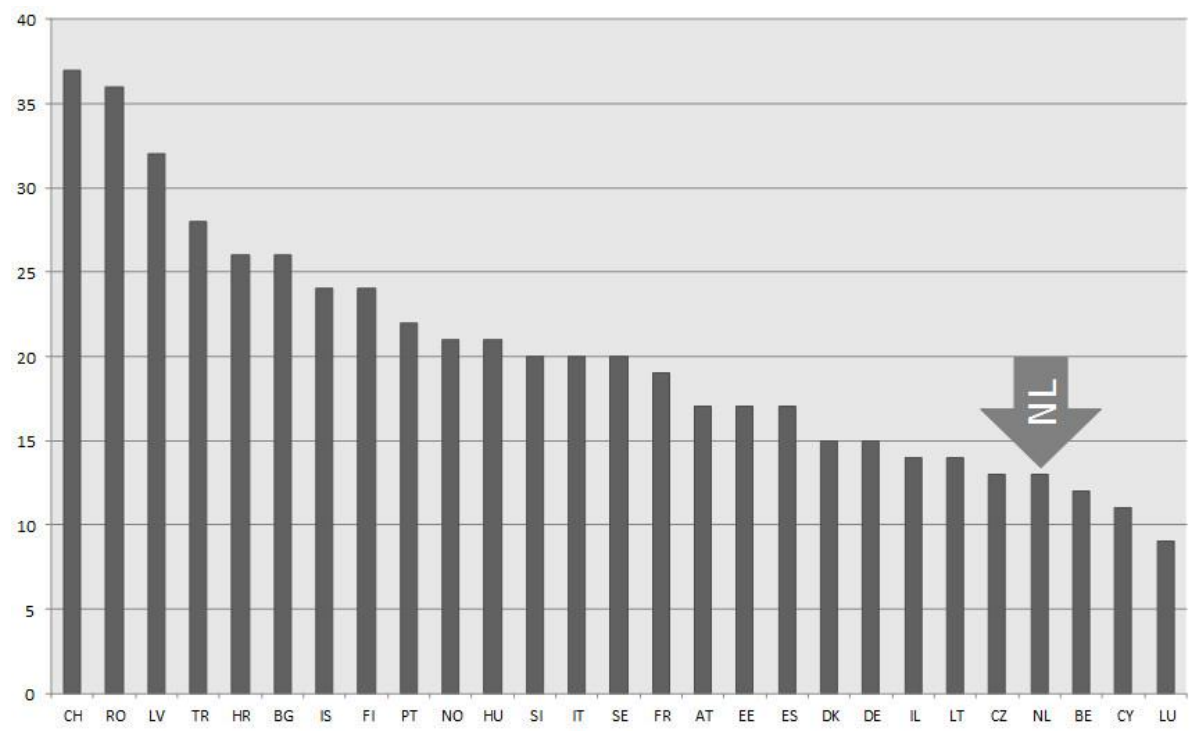

Figuur 4b Aandeel van vrouwelijke hoogleraren in 2011 Bron: Monitor Vrouwelijke Hoogleraren

Zoals jullie kunnen zien in figuur $4 \mathrm{~b}$ bungelt Nederland en dus ook de Universiteit Maastricht internationaal onderaan als het gaat om het percentage vrouwelijke hoogleraren. Wat gaat mis? Hebben vrouwen geen ambitie, heeft Nederland onvoldoende vrouwen die hogerop willen, of werken ze te veel in deeltijd? Niets van dit! Eén van de weinig onderbouwde verklaringen is een genderbias in de werving- en selectieprocedure. ledereen kiest die mensen die op hem of haar lijken, en aangezien de academische wereld wordt gedomineerd door mannen, kiezen zij het liefst ook mannen. Lieve mannelijke collega's, gender is misschien voor jullie geen issue, maar kijk en luister eens naar de vrouwelijke talenten, en zwijg niet over hun capaciteiten bij bevorderingen, en bij het samenstellen van leescommissies en andere adviescommissies.

Ik hoop dat ik jullie in deze rede overtuigd heb van het belang van HTA voor elk soort onderzoek. 


\section{Eed van HTA}

Ik, ..., zal oprecht en eerlijk, naar mijn beste kennis en kunde, altijd een economische evaluatiestudie uitvoeren en altijd een gezondheidseconoom/HTA deskundige raadplegen, wanneer ik een interventie evalueer... ..., "Zo waarlijk helpe mij God Almachtig!" ("Dat verklaar en beloof ik!")

Figuur 5 Eed van HTA

Als jurist wil ik dit natuurlijk zwart op wit hebben en speciaal voor iedereen heb ik de eed van het HTA onderzoek opgenomen achter in mijn rede. Daarnaast heb ik laten zien, dat het huidige methodologische raamwerk van HTA niet voldoende is om een brede en valide maatschappelijke economische evaluatie van innovaties op het gebied van publieke gezondheid en integrale zorg te garanderen. Om te gaan van "niet horen, niet zien en zwijgen!" naar "horen, zien en niet zwijgen!" zijn additionele methoden nodig. 


\section{Dankwoord}

Dames en heren, het is nu bijna voorbij maar niet voordat ik mijn dank zeg aan iedereen die dit het mogelijk heeft gemaakt. Hoewel me de tijd ontbreekt om iedereen persoonlijk te bedanken, wil ik voor een aantal personen een uitzondering maken.

Mijn dank aan de Stichting Wetenschapsbeoefening UM, het College van Bestuur van de Universiteit Maastricht en in het bijzonder de oud-decaan van de FHML, Martin Paul, voor mijn benoeming.

Ik wil graag mijn begeleidingscommissie bedanken. Onno van Schayck, directeur van onderzoeksschool CAPHRI en Albert Scherpbier, decaan van de faculteit FHML, wil ik bedanken voor de steun voor deze leerstoel. Dirk Ruwaard, dank voor jouw enorme inzet voor de vakgroep Health Services Research en ook voor het vertrouwen in mij. En ten slotte, Monique van Thienen voor de ambtelijke ondersteuning bij deze commissie, ik ben benieuwd naar hoe vaak we bij elkaar gaan komen.

Bij onderzoek doen gaat het voor mij niet om de eindbestemming, maar om de weg ernaar toe. Ik reis niet graag alleen, dus ben ik blij dat ik samen met jonge onderzoekers en andere begeleiders deze weg mag gaan.

Dank aan alle externe promovendi, onder andere Charles Adarkwah en Marcel Hofman, en interne promovendi - waarvan de meeste al eerder heb genoemd- dat ik soms jullie reisgenoot mag zijn. Ik heb voor jullie allen veel bewondering.

Hoewel ik door het land heb rondgezworven ben ik uiteindelijk "Made in Maastricht". Ik dank alle docenten van GGK, Beleid en Beheer, Epidemiologie en Rechten voor hun bevlogen manier van onderwijs geven.

De begeleiders van mijn promotietraject, Tom Groot, Hans Maarse, André Ament en Gerhard Blaauw, hebben mij de eerste keer naar dit podium gebracht, fijn dat jullie vandaag hier zijn.

Leden van de gemeenschap gezondheidseconomie en HTA, we gaan ervoor zorgen, dat veel mensen de eed van HTA zullen ondertekenen. 
Interdisciplinair en interfacultair onderzoek doen is voor een HTA-er een gegeven. Dank aan alle collega's, waarmee ik mag samenwerken, zowel binnen als buiten de faculteit, nationaal en internationaal.

Lieve collega's van HSR en van het programma HTA fijn dat jullie mijn naaste collega's zijn. Aggie Paulus, Arno van Raak en Siebren Groothuis dank dat ik altijd met jullie mag sparren. Lieve Brigitte, lieve Suus dankzij jullie sta ik hier... het was weer een heel groot plezier!;-)

Alle dank aan ook ex-collega's en hun partners, van epidemiologie, medische sociologie, MUMC neurochirurgie, de UVA, RIVM en het irV, maar vooral de oudcollega's van Economie van de Gezondheidszorg en van de vakgroep Beleid Economie en Organisatie van de Zorg.

Lieve André, de bakermat voor HTA in Nederland ligt in Maastricht. In deze Alma Ata was jij voor vele decennia de stimulerende factor. Ik hoop, dat je trost bent dat 2 promovendi van jou uiteindelijk hoogleraar zijn geworden. Ik mis je humor en jouw relativeringsvermogen nog elke dag.

Het "klasje van Martin Paul", de vrouwelijke toptalenten Ilja Arts, Diana Dolmans, Suzanne Frints, Sylvia Heeneman, Caroline van Heugten, Mirjam Oude Egbrink en Matty Wijenberg', jullie zijn een inspiratiebron.

"Niet zeuren, jij wilt hoogleraar worden dus die oratie hoort erbij", tekent de taal van een echte vriendschap, lieve vrienden en vriendinnen, ik hoop dat jullie een kleine indruk hebben gekregen van wat ik dagelijks doe. Dank voor de nodige afleiding! Lieve Mariëlle en haar gezinnetje, sinds EGZ en Sorento hebben we lief en leed gedeeld, dank voor je vriendschap. Misschien beginnen we ooit een poezenpension. Lieve Diane, dank voor alle gezelligheid, opbeurende woorden en veilige ritjes. Dankzij jou is menige tekst rondom deze oratie in goed Engels. Thanks!

Of je alleen loopt of ik in groep, zei ik al eerder, maakt een enorm verschil. Lieve HOHA-runners, dat geldt zeker voor jullie. Door jullie hartelijkheid is bewegen minder een straf. Na deze oratie loop ik of ...wandel ik, graag met jullie weer Heuvel Op en Heuvel Af. 
Lieve familie, in het bijzonder van de Evers kant; we komen elkaar de laatste tijd vooral tegen bij iets minder leuke gelegenheden. Voor mij ook een reden om een extra feest te bouwen rondom mijn oratie. Wellicht glimmen er "boven" ons ook een aantal van trots.

Betste sjweierfamilië, iech hoof dat mieng oratie waal jet duudlieger woar vuur uuch, dan wie 't Bochezer en Zumpelvelder dialect in 't bejin woar vuur miech. Sjun dat dier miech zoeë jód opjenoame hat in ung familië.

Het devies bie oos toes was altied "det waat ze gelierd hubs, numme ze dich neet mie aaf". Leve Pap en leve Liza dank veur alle leefde en steun. Leev mama Tiny in dien sjrif heels dich all allezelaeve alle oetgaeve bie. Doe höbs mich liere sjrieve en raekene, dankzij dich en pap sjtaon ich hie. Ich mis dich altied, mer veural op daes memènte.

Leve Loek doe vènjs dit ene haop bómbarie. Mer 't huurt er noe einmaol bie. Dank veur dien leefde, dien enoemelijke steun, en diene humor, auch al sjnap ich um neet altied.

Leve Lara en leve Vera, es ich plat kal, spreken jullie Nederlands terug. Veur leefde besjtuit gelökkig gein taol. Leef sjnóbbele, ich höb uch leef.

Leef luuj ut is UM! Ik heb gezegd. 


\section{Referenties}

Volgen nog 